\title{
An Evaluation of Turkish Mortgage System From the Perspective of Global Economic Crisis
}

\author{
Mustafa Topaloglu \\ Beykent University, Istanbul, Turkey
}

\begin{abstract}
Turkish mortgage system was established by the number of 5582 and the title of The Law Amending the Laws Related to Housing Finance System in 2007. Even though the entry into force of this Act expressed as "pay the rent as the landlord-performing”, not bringing up short term of the interest rates of a housing loan was observed. In fact, mortgage application could not be branch out yet. Distinguishing feature of the mortgage system is to sell in the capital market by issuing mortgage-backed securities. Gained fund from this sale creates the mortgage money. Using this fund for financing provided by banks as a result of re-housing resource for the consumer to pay the cost of housing loan interest rate relatively goes into a decline. Meanwhile, after the abundance of finance in the world, the so-called subprime mortgage, loans to non-qualified borrower, triggered the world economic crisis occurred. It may well be that, Turkey was unimpressed by the crisis because of the not being set secondary mortgage market. All the public in charge of economy has introduced prevention of packages of measures.
\end{abstract}

Keywords: mortgage-backed securities, mortgage bonds, Turkish mortgage system

\section{General View to Housing Finance System}

Housing problem has become one of the greatest problems of mankind since the beginning of the civilization. It is doubtful that the finance system procuring supply of loan under more reasonable conditions by establishing a bridge between landlords and house buyers has an important role in solution of this problem. Besides, this fundamental function, the housing finance system would contribute to the economic development by stimulating development of the financial markets and construction sector to boom.

The most developed and rooted housing finance system in the world is the USA mortgage application. The mortgage that is a system of loan secured by real property was developed in England in the middle age and subsequently transferred to the US Law.

That, in USA, the state provided mortgage loans by securing the debt through the governmental authorities after the great economic depression in 1930s resulted in both explosion of the housing sector and creation of capital market based on real property at international level.

\section{Mortgage Concept and Its Development in USA}

The mortgage is a type of security arisen in medieval England where interest was prohibited. According to the mortgage system, the creditor takes over the possession of the real property—owned by the debtor-in

Mustafa Topaloglu, Ph.D., Professor of Commercial Law, Faculty of Law, Beykent University.

Correspondence concerning this article should be addressed to Mustafa Topaloglu, Topaloglu Law Firm, Inonu Cad.Sitki Kulak Is Merkezi Kat: 2 Adana, Turkey. E-mail: mtopaloglu@mustafatopaloglu.av.tr. 
consideration of the loan granted by the creditor, since the creditor is unable to collect interest, and does not deduct the rental costs and other incomes gained from the real property on the due date of the loan (Hazeltine, 1993, 1994; Nelson \& Whitman, 2001). From the viewpoint of the debtor, the real property not under the possession of the debtor during the term of the mortgage is just like a dead investment. The relevant type of security is called as mort-gage, which literally means dead (“mort”) pledge ("gage”) (Werner, 2002; Karp \& Klayman, 2003).

The USA mortgage application does not fully meet the hypothecation—backed credit system in civil law countries. Ownership of the real property, offered as guarantee, is transferred to the creditor or escrow called as trustee at the time of establishment of mortgage. However, this transfer is conditional and the ownership returns to the debtor upon fully payment of the debt. In some states (title states), even if the creditor is entitled to take over the possession of the mortgaged real property upon entry into effect of the relevant agreement, the creditors do not exercise these rights until occurrence of any default (Sturges \& Clark, 1928; Moringiello, 1996; Küçük, 2007).

In the US Law, the conditions according to which the creditor shall become absolute title owner of the pledged real property in case of failure in payment of the debt during conclusion of the agreement (lex commisoria) are considered null and void (Rubin \& Strohchein, 1993, 1994; McNaB, 2000). In case the debt becomes due and payable, the creditor is liable to initiate foreclosure process with respect to the mortgaged real property (Werner, 2002). At the time of drafting the agreement, if the creditor is granted the power of sale of the real property, the creditor shall exercise this right and sell the real property by the way of auction (Kratovil, 1979, 1980). However, the courts consider even a minor defect in such sales as reason for cancellation (Nelson, 1988). Therefore, judicial foreclosure, another type of sale, is exercised more widely (Wright, 2005; Pence, 2003).

It is possible to transfer or assign the mortgage to third parties in the US. The transfer or assignment is made by the way of delivery or endorsement as it is for the valuable papers. As for the regular mortgage, besides the endorsement or assignment, official registration is additionally required (Grimes, 1954). As this kind of mortgage is frequently transferred in the financial markets, the registration requirement causes great difficulties. In order to eliminate such difficulties, Mortgage Electronic Registration System (MERS) was established.

Mortgage-backed securities are subjected to securitization and transferred to the secondary market. For this transaction, various mortgage loans are firstly gathered to form a pool. Certificates representing the mortgage loans in this pool are sold to the investors in the secondary market (Bradner, 1987). The investors take shares over the return of the loans in the pool only against these certificates bought by them. On the contrary, they do not share any cost item of the pool and their rights to the same may not be restricted to a single or a few mortgage loans either. The creditor gets liquidity from the pool, formed by the way so, as to re-use the same in the housing finance (Werner, 2002).

\section{Turkish Mortgage Law}

Draft Law known as "mortgage” or "tutsat” (“hold-sell”) law according to Turkish public opinion was enforced by Law regarding Revision of the Housing Finance System dated February 21, 2007 and numbered 5582. Law No. 5582 was entered into force upon publication in Official Gazette dated March 6, 2007 and numbered 26454 in an instant moment within the time of abandonment of the hopes. 
The relevant arrangement does not stipulate a separate and independent law, which might be called as Mortgage Law or Mortgaged Housing Finance Law. Instead, a model was tried to be created by making several insertions into Execution and Bankruptcy Law, Financial Leasing Law, and Law regarding Protection of the Consumers, several tax laws particularly into the Capital Market Law.

Principally, the relevant law aims at providing housing loans under more reasonable conditions by establishment of a corporate relation between the investors and consumers. Additionally, formation of a secondary market, which would possibly support development of the housing loan market of a specific size, with the help of corporations, rules and financial instruments, is also among the purposes of the law (Yalciner, 2006).

\section{Scope of the Turkish Mortgage Law}

Mortgage Law No. 5582 is applied to the procedures and transactions of "housing finance". Fundamentally, supply of loan to the consumers constitutes the housing finance. Except for the purpose of buying a house, use of consumer loan by the consumer by the way of mortgage of his/her existing real property in order to satisfy its monetary needs is also considered to be the housing finance. Leasing of the houses by the way of financial leasing is considered as another type of the housing finance. Extension of loan for the purpose of refinancing of the aforesaid three types of loan is considered by the law as the housing finance as well. Consumers, being the parties to the loan and financial leasing agreements within the scope of the definition of mortgaged housing finance arranged before March 6, 2007-the date when the Mortgage Law enters into force - may apply to the finance corporations with which they entered into agreements - by the date of June 6, 2007, and may ask that their relevant transactions would be taken out of the scope of the housing finance. The relevant transactions — arranged before the effectiveness date of the law—of the consumers failed to apply and request within the aforementioned statutory period is considered "housing finance transactions" and get involved in the scope of the law. Thus, the law accepts that previous mortgaged housing loan transactions shall automatically be considered mortgaged housing finance transactions and enables the non-intending consumers to apply within three months as of the date of publication and grants the option of opt-out from the scope of housing finance.

However, rights regarding early payment (as per Article 10 of the former Consumer Protection Law) of the consumers, being parties to previous-dated agreements involved in the mortgaged housing finance system by not benefiting the relevant option under Provisional Article 11 have been protected as the acquired rights. Accordingly, if the relevant consumers pay the total debt at lump sum or pay the installments earlier than the due dates, the relevant housing finance corporation shall be obligated to make interest and commission discount. Naturally, imposition of "early payment penalty" brought by the housing finance system cannot be in question.

\section{Parties in Mortgage Law}

Since the housing finance system is initially a loan transaction, it is entered into by and between the mortgaged finance corporations and the consumers using the loans. After conclusion of mortgaged housing finance agreement; at the stage of securitization, mortgage finance corporations and the investors are in question. According to Article 12 of Mortgage Law No. 5582, "housing finance corporations" consist of banks directly extending loans to the consumers for the purpose of house financing or conducting financial leasing as well as financial leasing companies and financing companies deemed appropriate by the Banking Regulatory 
and Supervisory Agency (BRSA) to carry out housing finance activities.

Furthermore, as per Article 14 of the Law, a new corporation was established under title of "mortgage finance corporations" exclusively for the purposes of acquisition and transfer of the receivables arisen out of the housing finance and management of the securities consisting of the acquired receivables (Lea, 2006).

The mortgaged housing finance was intended to be solved according to the consumer law composition. Accordingly, those considered to be consumers as per the Consumer Protection Law may benefit from this system. In addition, it is intended that real persons in the capacity of members of the cooperative housing would benefit from the Mortgage System directly or indirectly by considering the same in the consumers category.

\section{Mortgage-Subject Matter of the Housing Finance Transaction}

The housing finance system was developed based on the concept of mortgage in the US. The concept of mortgage does not have fully-equivalent concept in the Turkish Law. In the US, besides the fact that the real property is directly provided as guarantee for the debt, the fiduciary assignment transactions are considered mortgage and sometimes even issuance of a promissory note which includes an expression related to guarantee of a real property thereon is assessed within the scope of the mortgage.

Law No. 5582 only mentions loans for which mortgage is given as guarantee and no provision has been established relating to the mortgage other than those loans. In this case, the mortgages, to become subject matter of the housing finance transaction, would be subject to provisions of Civil Law No. 4721. The parties, intending to establish mortgage within the scope of this system, are absolutely required to choose any of the principal mortgage and high limit mortgage (Onal \& Topaloglu, 2007).

\section{Mortgaged Housing Finance Agreement}

A long article titled Housing finance agreements was inserted into Article 10 of the Law regarding Protection of the Consumers as Article 10/B by the Mortgage Law. All the matters from obligatory contents of the housing finance agreement to the interest rates, from early payment to default, from appreciation to sales and discharge, which may possibly become subject matter of a separate law, were arranged by this article failed to comply with the law making technique.

The housing finance corporations are obligated to give the consumers pre-contractual informatory form including the information on the loan before starting the transactions. In order to ensure that the consumer is able to adequately evaluate the legal relation, which would bind the consumer for a long term, execution of housing finance agreement before completion of one business day as of receipt of the relevant form is prohibited.

\section{Interest and Early Payment in Mortgaged Housing Finance Agreement}

Terms and conditions set forth in the housing finance agreement obligated to be concluded in writing may not be amended against the consumer. The interest rate in these agreements may be determined as fixed or variable or determined by using both methods. In case of determination of the rate as fixed rate, it is not possible to change the rate determined at the beginning without the common consent of both parties.

In case of determination of the rate as variable, the rate determined at the beginning might be changed based on an index generally accepted both in the country and abroad as specified by the agreement. However, the new repayment amount, produced by application of the altered interest rate, may not exceed the repayment 
amount specified by the agreement at the beginning. The housing finance corporation, taking a long term risk by the way, would have the chance to adapt the agreement with the changing economic conditions. Stipulation that the repayment amount shall not exceed a specific limit prevents the obligation of the consumer to encounter a payment schedule which the consumer is unable to pay as a result of interest adaptation. Furthermore, since the interest rate in the variable interest application would be lower than the fixed rate, this application would in fact be inure to the benefit of the consumer much more (Alp, 1996).

The consumer may not only pay the total amount owed by the consumer to the housing finance corporation beforehand, but also make more than one payment simultaneously before the due dates. In both cases, the housing finance corporation is liable to make the required interest discount for the installments paid before the due dates. However, the early payment constitutes prepayment risk in respect of the creditor finance corporation. Therefore, Law No. 5582 grants to the finance corporation to ask for early payment fee (in fact penalty) not to exceed two percent of the early paid amount in cases when the interest rate is determined to be fixed (Topaloglu, 2009).

\section{Default by the Consumer Using Mortgaged Housing Loan}

The relevant law arranged the matter of default with regard to the mortgaged housing finance loans as similar to the consumer loans. Accordingly, the housing finance corporation shall be liable to serve a notice to the defaulting consumer within five business days after the date of default by a return receipt registered mail.

Law No. 5582 permits insertion of acceleration clause into the housing finance agreement as it is for the consumer loans. The housing finance corporation may ask for the payment of the entire of the outstanding debt, in case the consumer falls in default to pay two successive installments, provided that this clause is fixed by the agreement. However, in order that the housing finance corporation is able to exercise such right, it is obligated to give at least one month duration and make warning related to the acceleration clause. In the US, the debtor, who falls in default, is given payment duration of at least five weeks. It has been a rational application that the payment duration being one week for the consumer loans was increased up to one month for the housing finance loans. However, the consumers, whose salaries decreased for conjectural reasons, were possibly given a further duration of three months. In addition, pursuant to this evaluation, it should also be noted that repayments to be collected from the consumers under the housing finance system constitute guarantees for mortgage-backed securities quoted on the secondary market.

If the payment is not made within the statutory time despite the warning on acceleration clause, the housing finance corporation should terminate the agreement if it intends to collect the outstanding debt. In case of termination of the agreement for the purpose of collection of the entire balance due, the mortgaged real property is required to immediately be offered for sale.

\section{Securitization of Receivables Arisen out of Housing Finance}

Fundamental benefit of the mortgage system is to create a separate fund called by the western countries as "mortgage money" by the way of securitization of the receivables arisen out of the housing finance. This created fund is returned to the system by providing mortgage loans to the consumers, intending to buy and own houses. Moreover, the banks had used the loans obtained from the foreign finance corporations or interests of deposits before entry into force of the Mortgage Law for financing of the house loans. Since the fund, being supplied from the mortgage system by the way of securitization, is more cost-effective than syndication loan or 
deposits interest, the interest rates of the mortgage loans are expected to be lower than the interests of the classical housing loans. When the system operates so, longer term loans with lower interest rates might be extended; perhaps, then, the dream of "owning a house just like paying rents” would possibly come true.

On the other hand, 15-20 years maturities of mortgage loans would enable issuance of such longer maturity investment instruments. The investors, intending to make long term investments, would get the chance to choose a reliable investment instrument. The relevant securities might bring in pension funds and foreign investors to our country for investment.

As explained as the rationale of Law No. 5582, securitization of the receivables regarding the housing finance would be made particularly by "covered bond", a type of security used in the Europe Continent and “mortgage based securities” (Baressi, 2005; Ferran, 1992). In the Mortgage Law, two new types of securities called "mortgage-covered bonds" and "mortgage-backed securities" were anticipated (Berkant, 2005). These two new types of securities to be issued in ISE upon registration with the CMB (Capital Market Board) are completely different than the mortgaged debt bond and annuity bonds stipulated by the Civil Law.

\section{Mortgage-Covered Bonds}

According to Law No. 5582, both the housing finance corporations and mortgage finance corporations might act as issuers of mortgage-covered bonds. The mortgage-covered bonds are defined by Law No. 5582 as the debt instruments issued in consideration of the assets in the cover pool, former under general liability of the issuers (Article 13).

The cover pool consists of receivables covered by establishment of mortgage on houses and other real properties with occupancy permits, substitute assets and contracts entered for the purpose of hedging the same. Amount, exceeding $75 \%$ of the value of the houses with occupancy permits, of the receivables covered by the way of establishment of mortgage on the relevant real properties and amount, exceeding $50 \%$ of the value of the relevant real properties, of the receivables covered by the way of establishment of mortgage on the other real properties with occupancy permit, are not taken into consideration in calculation of the cover value. The substitute assets herein refer to government debt securities, treasury-guaranteed securities and similar securities deemed appropriate by the CMB. A guarantee supervisor is appointed to monitor and supervise the cover pool.

Securities in the cover pool may not be disposed, pledged or provided as guarantee for any purpose other than guarantee and may not be attached, subjected to preliminary injunction and bankruptcy including the purpose of collection of the public receivables until redemption of the mortgage-covered bonds. A strong guarantee function was procured by the way of elimination of right of disposition of the issuers on the receivables and guarantees involved in the cover pool and by the way of ruling that no intervention in the same is allowed. The mortgage-covered bonds are in the form of debt securities of the issuers. Therefore, holders of the mortgage covered securities may apply for other assets of the issuers since they cannot get their receivables from the cover pool.

\section{Housing Finance Fund and Mortgage-Backed Securities}

Another method of securitization of the mortgage-backed securities is the issue of mortgage-backed securities through the funds to be established. The Law No. 5582 stipulates establishment of housing finance fund with regard to this method, called as off-the-balance sheet method. The housing finance fund was structured as similarly as the "trusts" resident abroad and securities investment funds resident in Turkey. 
The housing finance fund consists of the funds collected in consideration for the issued mortgage-backed securities and the assets created according to the principles of fiduciary ownership on the account of the mortgage-backed securities (Onen, 2006). Incomes generated from cash flows of the securities transferred to the fund belong to the investors.

The housing finance funds do not have legal personality and are separate and independent from the assets of the founder since they are off-the-balance sheet. It is forbidden that the assets of the fund would be subjected to disposition, attachment and injunction or bankruptcy for any other purpose until redemption of the mortgage backed securities.

In case mortgage-covered loans or receivables are involved in the fund portfolio, the matter of transfer of the loans or receivables to the fund is registered in declaration column of the relevant real property. The founders represent and manage the fund in accordance with the provisions of the attorney agreement to the extent that they would protect the rights of the holders of the issued mortgage-backed securities. Unless the founders additionally guarantee, they would not be responsible for the portions-not covered from the assets of the fund —of the repayments of the issued capital market instruments.

\section{Why the Mortgage System in Turkey Was not Affected by the Global Economic Crisis}

Turkish banking sector generally went through the crisis with a stronger standing. It is possible to say that this good standing is based on more than one factor. Restructuring after 2001 has an important role on such standing of the banking sector. However, as for the period before 2001 in Turkey, it might be stated that despite there existed in fact a basis for an explosive crisis in Turkey, the Central Bank prevented the crisis unlike what Federal Reserve System in U.S. (Central Bank) did. As a result of reforms made after 2001 and financial discipline applied successfully by the government, public budget deficit was considerably brought under control and accordingly public sector borrowing requirement decreased. This resulted in reduction in crowding-out effect of the state in the debt markets. Indeed, the fundamental reason of the crisis arisen both in 1994 and 2001 was the state's debt service, which has become unsustainable and the crowding-out effect caused by the same in the market. As a consequence of elimination of the fundamental reason for such effect by means of measures taken after 2001, budget deficit and inflation in parallel with the budget deficit tended to decrease. At this juncture, Turkish banks, unable to provide loans generating higher income-bearing lower risk for Treasury started to look for new addresses for their monetary sources such as foreign banks. This address has been the households in Turkey just as it was in the U.S.. The housing loans, credit cards, and consumer loans have grown up considerably. However, despite the banks' efforts such as opening new branches, making advertisements, organizing campaigns, a growth in parallel with those in many countries in the world has not occurred. The most important reason for failure of such a growth is that borrowing for buying house has not become so attractive. This was always originated from the interests remained higher. Even in the lowest level, interests of the housing loans did not drop down below monthly $1 \%$ or annually $12 \%$. The major reason for this is that the Central Bank keeps the interests higher. Even though the higher interests constitute a significant obstacle for growth, the Central Bank achieved to control the growth while at the same time controlling the inflation by this way. The growth rates remaining at mid-levels impeded growth of the bank loans more than the deposit basis. If the Central Bank of the Republic of Turkey had decreased down the interests, the banks would possibly have used all of their resources against the increasing loan demands and made available high-risk loans among their assets; and furthermore, they would have progressed further by 
going beyond the deposit resources and trying to make higher borrowings in the country and abroad. Therefore, unlike U.S. and Europe, amount of all the mortgage or real property sales with housing loans could not exceed $10 \%$ of the total real property sales.

On the other hand, housing finance or operation of housing loan in Turkey presents that a possible crisis based on the mortgage system would not arise. In fact, the banks in Turkey do not expel insolvent customer, fail to timely pay back the loan, and contrarily do keep these customers and thus intend to collect default interests higher than the current interests.

That is, if a customer fails to pay his credit card within the statutory time, only pays the minimum amount, delays to repay his consumer loan, fails to pay his housing loan installments for successive two months, then this customer would be considered the most profitable customer for the banks. This is because the banks both establish mortgages on real properties and seek sureties and make insurances including life insurances. By this way, the housing loans have stronger guarantee apart from the mortgage. Within the scope of the executive proceedings initiated due to failure to re-pay the housing loans, sale of the mortgaged real property is easily procured by the way of tender. Moreover, housing concern of the public is a factor facilitating disposal of the mortgaged real properties.

In some cases, the mortgaged real properties might be sold upon the consent of insolvent debtor without any need for an executive proceeding. In addition, balance remained due to sale of the mortgaged real property might be collected from the insurance and sureties. Nevertheless, aids and supports provided by friends or relatives due to strong family ties do have shares in liquidation of the mortgaged housing loan receivables. The housing demand of the public, not dropped down despite the crisis in Turkey, has not caused any decrease in the house prices. Ever-increasing house prices also facilitated realization of the mortgaged houses at higher amounts. Therefore, it is not so possible that a crisis come out of failure in payment of housing loans as it is in U.S..

Moreover, although related laws and regulations and system have been enforced up to date in Turkey, issuance of mortgage-backed securities or mortgage-covered bonds could not have been achieved. In other words, derivative instruments based on mortgaged securitization could not develop either. Even though name of the system is mortgage-housing finance system, it could not improve on a normal consumer loan. The banks extended the loans - obtained abroad under syndication loan — to the consumers under mortgage loan. In any case, it has not been possible to provide finance to the housing loan due to mortgage pool, which is the determining item and composed of mortgaged housing loans. Therefore, a mortgage crisis, triggered by insanity of an immoderate and limitless securitization such as Anglo-Saxon instance, has not occurred in Turkey. In fact, even though the mortgage system operates through securitization in real terms, it is considered that a housing crisis just like the one in the U.S. would possibly not occur. Likewise, since housing loan is able to be extended up to $75 \%$ of the value of the real property in Turkey, LTV (Loan to Value) rate would not in any case reach $100 \%$. However, before the crisis in U.S., not only the whole value of the real property had been credited but also mortgage had been provided for maintenance and repair as well as insurance expenses and the LTV rate had reached $120 \%$. The banks that are under strict supervision of the BRSA carry out considerable researches on creditworthiness of the customers. In appraisal of the real properties-for which mortgage is to be sought - to be carried out by the appraisal companies under strict discipline of the CMB, values are determined made as close as the just values of the real properties. Consequently, since the mortgage loan is procured to the creditworthy companies based on mortgages established over the just value, even if default occurs, no problem 
is encountered in collection of the loan. Additionally, although the mortgage system operates in real terms, it seems so far that problems might arise even after securitization since quite strict guarantee-harmonization principles were established by communiqués of the CMB for loans and mortgages to be involved in the mortgage pools.

\section{Conclusion}

In Turkey, infrastructure of the mortgage system or, in legal terms, housing finance system was constituted by Amendment Law dated February 21, 2007 and No. 5582 regarding the Housing Finance System and secondary arrangement of the securitization was formed by communiqués of the CMB. In essence, extension of loans to the consumers for housing purposes is the housing finance. That the consumer obtains consumer loan by establishing mortgage on his existing real property in order to satisfy a monetary need other than housing is also considered the housing finance. Leasing of the houses by the way of financial leasing is considered another type of housing finance. Extension of loan for the purpose of refinancing of the aforesaid three types of loan is considered by the law as the housing finance as well.

Securitization of the receivables regarding the housing finance would be made particularly by "covered bonds", a type of security used in the Europe Continent and "mortgage based securities". In the Mortgage Law, two new types of securities called "mortgage-covered bonds" and "mortgage-backed securities" were anticipated. However, the relevant securities could not have been issued until quite recently; so the banks extended the loans—obtained abroad as syndication loans— to the consumers as mortgage loans. In any case, it has not been possible to provide finance to the housing loan due to mortgage pool, which is the determining item and composed of mortgaged housing loans. Therefore, a mortgage crisis, triggered by insanity of an immoderate and limitless securitization such as Anglo-Saxon instance, has not occurred in Turkey.

In Turkey, the Central Bank's attempt of keeping the interests higher to control growth impeded decrease of the mortgage loans below $1 \%$ and this prevented increase of demands for mortgage crisis. In the global crisis period, unlike U.S. and Europe, amount of all the mortgage or real property sales with housing loans could not exceed $10 \%$ of the total real property sales.

In Turkey, the banks both establish mortgages on real properties and seek sureties and make insurances including life insurances. By this way, the housing loans have stronger guarantee apart from the mortgage. Within the scope of the executive proceedings initiated due to failure to re-pay the housing loans, sale of the mortgaged real property is easily procured by the way of tender. Moreover, housing concern of the public is a factor facilitating disposal of the mortgaged real properties.

In some cases, the mortgaged real properties might be sold upon the consent of insolvent debtor without any need for an executive proceeding. In addition, balance remained due to sale of the mortgaged real property might be collected from the insurance and sureties. Nevertheless, aids and supports provided by friends or relatives due to strong family ties in Turkey do have shares in liquidation of the mortgaged housing loan receivables. The housing demand of the public, not dropped down despite the crisis in Turkey, has not caused any decrease in the house prices. Ever-increasing house prices also facilitated realization of the mortgaged houses at higher amounts. Therefore, it is not so possible that a crisis come out of failure in payment of housing loans as it is in U.S.. 


\section{References}

Bradner., J. A. (1987). The secondary mortgage market and state regulation of real estate financing. Emory Law Journal, 36(1).

Burkhart, A. M. (1999). Lenders and Land. Missouri Law Review, 64(249).

Chaplin, H. W. (1890). The story of mortgage law. Harvard Law Review, IV(1).

Grimes, W. A. (1954). Mortgages: Effect of failure to record a mortgage assignment in Florida. Florida Law Review, 7.

Hazaltine, H. D. (1993, 1994). The gage of land in medieval England. Harvard Law Review, XVII.

Karp, J., \& Klayman, E. (2003). Real estate law (5th ed.). Chicago.

Kratovil, R. (1979, 1980). Mortgage law today. The John Marshal Law Review, 13.

Küçük, D. (2007). Mortgage insurance. TERAZI Monthly Legal Journal, 2.

Lea, M. (2006). Mortgage finance corporations. Istanbul: Turkey Hausing Finance Workshop.

McNab, W. A. (2000). Minnesota loss payable clauses in fire insurance policies: Falling short of the minimum coverage requirements. William Mitchell Law Review, 26.

Moringiello, J. M. (1996). A mortgage by any other name: A plea for the uniform treatment of installment land contracts and mortgages under the bankruptcy code. Dickinson Law Review, 100.

Nelson, D. A. R. (1988). Rosenberg v. Smidts: Dramatic Ramifacation for Nonjudical Foreclosure Sales in Alaska. Alaska Law Review, $V$.

Nelson, G. S., \& Whitman, D. A. (2001). Real estate finance law (4th ed.). St. Paul, MINN.

Onal, Y. B., \& Topaloglu, M. (2007). Real estate finance and law-Mortgage. Adana.

Pence., K. M. (2003). Foreclosing on opportunity: State laws and mortgage credit.

Rubin, M. H., \& Strohchein, S. P. (1993, 1994). Developments in the law. Louisiana Law Review, 55.

Sturges, \& Clark. (1928). Legal theory of real property mortgages. Yale Law Journal, XXXVII(6).

Topaloglu, M. (2007). Mortgage bonds and mortgage backed securities. Adana.

Topaloglu, M. (2009). Mortgage bonds and mortgage backed securities in Turkish law. Dedication to Prof. Dr. Ali Naim Inan, Ankara.

Topaloglu, M. (2010). Prepayment penalty in mortgage credits. Deducation to Prof. Dr. Attila OZER, Ankara.

Werner, R. J. (2002). Real estate law (11th ed.). Chicago-IL.

Wright, F. (2005). The effect of new deal real estate residential finance and foreclosure policies made in response to the real estate conditions of the great depression No.1. Alabama Law Review, 57.

Yalcıner, K. (2006). Mortgage Credits Ankara. 